\title{
Correction: Co-Infection with Mycobacterium tuberculosis Impairs HIV-Specific CD8+ and CD4+ T Cell Functionality
}

\section{The PLOS ONE Staff}

\section{Notice of Republication}

This article was republished on May 5, 2015, to correct Figs 1-3, which were missing several panels. Please download this article again to view the correct version. The originally published, uncorrected article and the republished, corrected article are provided here for reference.

\section{Supporting Information}

S1 File. Originally published, uncorrected article.

S2 File. Republished, corrected article.

(PDF)

\section{Reference}

1. Chetty S, Govender P, Zupkosky J, Pillay M, Ghebremichael M, Moosa M-YS, et al. (2015) Co-Infection with Mycobacterium tuberculosis Impairs HIV-Specific CD8+ and CD4+ T Cell Functionality. PLoS ONE 10(3): e0118654. doi: 10.1371/journal.pone.0118654 PMID: 25781898

\section{G OPEN ACCESS}

Citation: The PLOS ONE Staff (2015) Correction: Co-Infection with Mycobacterium tuberculosis Impairs HIV-Specific CD8+ and CD4+ T Cell Functionality. PLOS ONE 10(5): e0127763. doi:10.1371/journal. pone.0127763

Published: May 20, 2015

Copyright: $\odot 2015$ The PLOS ONE Staff. This is an open access article distributed under the terms of the Creative Commons Attribution License, which permits unrestricted use, distribution, and reproduction in any medium, provided the original author and source are credited. 